\title{
An Intertextual Study of Pygmalion Myth: George Bernard Shaw Interprets an Ovidean Tale about Transforming
}

\author{
Dr. Saman HASHEMIPOUR ${ }^{1}$, Asya Vedia GÜVENSOY ${ }^{2}$, Dilara ARAP ${ }^{3}$
}

\author{
${ }^{1}$ Assoc. Prof., Faculty of Humanities, Girne American University, Cyprus \\ smnpour@gmail.com \\ ${ }^{2}$ Department of English Language and Literature, Girne American University, TRNC \\ asyaguvensoy@outlook.com \\ ${ }^{3}$ Department of English Language and Literature, Girne American University, Cyprus \\ dilaraagat96@gmail.com
}

\begin{abstract}
Pygmalion, a play which is written by George Bernard Shaw is mainly about the story of a poor girl named Eliza Doolittle who is transforming into an upper-class member by the help of two professors, named Higgins and Pickering. The primary purpose of this paper is to analyze the theme of transformation in the play by focusing on the subjects of identity and self-identity, the importance of appearance, language and communication issues. The story has a mythological background and got known by Ovid's poem, "Metamorphoses." The mythological story is reflected in many poems, drama plays and short stories written by authors globally. Intertextual references to the myth in Rumi's Dīvān-e Šams-e Tabrīzī, Nader Naderpour's poetry "Bot-Taraash," and Gholām-Hossein Sä'edi's play, "Pygmalion." Some short stories with references to the myth such as; "The Birth-Mark," by Nathaniel Hawthorne and Sadegh Hedayat's "The Doll Behind the Curtain" are other texts that their similarities with Ovid's poem are analyzed in this study.
\end{abstract}

Keywords - Pygmalion, Ovid, Metamorphoses, Transformation, Mythology, George Bernard Shaw

\section{INTRODUCTION}

Pygmalion, by George Bernard Shaw (1856-1950), clearly referenced to a mythical story. Like all of Bernard Shaw's great dramas, Pygmalion is a complicated story. As soon as one starts reading-even without any background knowledge about literary elements - it can be seen that a different way of the narration had been used in this drama. On the island of Cyprus, Venus rose from under the sea and held a special celebration with great beauty and special rituals. The calves, like snow-white horns, were sacrificed for her. The fragrant smell of perfume wrapped around countless altar ways throughout the island. Masses of people came to visit her temple while all unhappy lovers gifts to pray and request her to soften the heart of their lovers. Pygmalion also attended and asked the goddess to make him acquainted with the beauty of the statue. To show him that his prayer is approved, Venus fired altar in front of Pygmalion for three times. Later, Pygmalion called the statue which became a woman named Galatea, and their son, Paphos, named that city with that temple, Venus.

\section{BACKGROUND OF PYGMALION MYTH}

The title of the play is a reference to Ovid's famous Latin narrative poem, "Metamorphoses". Pygmalion gets its name from an ancient Greek mythological legendary figure who was believed that he has lived in nowhere other than Cyprus. Pygmalion is a sculptor, who falls in love with a statue that he had made, according to Ovid's poem in the book ten of "Metamorphoses." (Ovid, 277-279) According to Ovid's poem, Pygmalion was a Cypriot sculptor who was not really interested in women; and he had a covenant never to marry at all. Finally, at his old age, he used all his art, skill and genius to create a beautiful statue for himself. Pygmalion could not forget the woman; he continued to work on the statue and eventually produced the most beautiful work of art. He caved a sculpture of that woman figure and finally, fell in love with it. He was wearing a beautiful and precious garment and admiring it but received no response from the cold, and motionless body. Frazer Wrote,

Pygmalion, a Phoenician king of Cyprus, who is said to have fallen in love with an image of Aphrodite and taken it to his bed. [...] Pygmalion was the father-in-law of 
Cinyras, that the son of Cinyras was Adonis, and that all three, in successive generations, are said to have been concerned in a loveintrigue with Aphrodite (Frazer, 316).

Feeling helpless, Pygmalion went to the temple of Aphrodite, goddess of love and beauty, and asked her to give life to the statue. Aphrodite realized the sculpture's love and restless emotions of the lover who brought life to the statue. Returning back home, he rushed to visit his mistress while the statue was a living woman's body on a pedestal. The female sculpture was named Galatea. Aphrodite presented at their marriage ceremony and gave their lives a special blessing and honour. This story has been well-liked by poets and writers and continuously rewritten in various forms. The first work of Pygmalion can be found in Rumi's Dīvān-e Šhams-e Tabrīzī;

I am a sculptor, and I cave new shapes and

forms each day;

but when I see you, all melt.

I am a painter, I create images and bring

them to life;

but when I see you, they all vanish.

Who are you, my friend, the promised lover

or deceitful enemy?

You ruined everything I build.

My soul has sprung from yours,

and it carries the scent of your perfume.

But without you my heart is shattered;

please, come back or let me leave this lonely

world. (Rumi, 1)

Iranian poet, Nader Naderpour's poetry "Bot-Taraash [Idolater]" in the form of a quadrilateral was written in 1956, imagines himself as an old sculptor who creates his lover with the marble of poetry in his imagination. Naderpour (1929-2000) calls the lover "an idol who does not notice the sculptor". (Naderpour, 1) He says, "You have stuck me in the dirt under your foot". (ibid.) The poem ends with a threat that "One night when the anger of your love makes me crazy / The shadows will observe that I will even destroy you." (ibid.) Gholām-Hossein Sā'edi (1936-1985) wrote his drama play, Pygmalion - a short play in three scenes - at the same year which published in Sokhan Magazine in 64 pages. (Hamraz, 1) First parts and the last two scenes are told through the dialogue of three event-watching characters - the cloud, the wind, and the fog. Pygmalion speaks as the central character in the second scene and narrates how the Pygmalion King falls in love with a statue. The king's unrequited love for the statue causes distress on him, and the king walks into the temple of Aphrodite-goddess of love and beauty-and commits Aphrodite several times each day to revive the statue. Eventually, Aphrodite responds to the young King's request and revives the statue. King Pygmalion is pleased, but the resurrected woman refuses the king. The king becomes more restless and distressed and goes to a witch to cry for help. Pygmalion does not know that the witch is fascinated by the statue, and he was looking for an opportunity to take Pygmalion out of her love. The witch suggests him to swim in the stormy sea during the Mephistopheles celebration. Drowning in the river, he calls out to the beloved Pygmalion for salvation, and the play ends when the immobile body of him and Pygmalion is lacklustrely seen on the stage.

Iranian author, Sadegh Hedayat (1903-1951) in his short story, "The Doll Behind the Curtain" which is published in 1933, narrates the tale of a young man's fascination for a silent statue behind a boutique window. (Hamidi, 1) The doll behind the story of a boy named Mehrdad and his fiancée, Derakhshandeh. Mehrdad is reared in the traditional family and is highly averse to women. After graduation from high school, Mehrdad's family makes him get engaged with his cousin and send to France where Mehrdad learns more about human relations and the power of traditional breeding which causes Mehrdad to ignore reality and continue to thrive in the fantasy world. At the end of the exam sessions, one day, he falls in love with a mannequin behind a shop window. He buys the model and takes it to Iran, where there is an emotional fluctuation between the love of mannequin as the artistic creation of humanity and the facts of humanity in his fiancé. Derakhshandeh discovers Mehrdad's love for the mannequin and tries hard to look like her silent rival. Mehrdad is about to forget the mannequin, but one day, in his room, he finds out that she is bending her head, holding her waist and looking at him while she steps toward him. Mehrdad fires a pistol and Derakhshandeh lies in a pool of blood.

In "The Birth-Mark," a short story by American author Nathaniel Hawthorne (1804-1864), Aylmer thinks of himself as a godlike creator who says that he will be happier than Pygmalion when he erases Georgiana's birthmark. By comparing himself to the mythologic sculptor, Aylmer believes that he is intelligent enough to create the perfect woman. Aylmer is not creating a woman where none previously existed; he is tampering with a perfectly beautiful woman. Moreover, American John Cheever's short story, "Metamorphoses" consists of four related sketches, translates legends into Westchester settings. Cheever (1912-1982)

\section{TRANSFORMING IDENTITY}

The theme of transformation plays a significant role in the play, Pygmalion and by Eliza, the writer shows how a person can turn to somebody new by little touches or by changing her appearance, talking, and behaviour. In Pygmalion, the writer's primary focus is to show the 
reader that when people are aimed to change, they can succeed in. However, a change may not be possible if the person does not believe in. In Pygmalion, not only by the touch of Higgins or Pickering but Eliza herself wants to experience an alter as well. Through the play, she achieves the change, and even her real father was not able to recognize whether it was her or not-even only by changing the clothes. On the other hand, another main aim of the writer is to make the reader investigate the theme of self-identity. Gradually, Eliza changes her appearance, her talking style, her clothing, but the matter of creating a new identity is unclear. No matter how a person aims to change, people are not able to escape their inner personality and real self. Vicki R. Kennell believes Shaw's play is the tension between fiction and reality. (Kennell, 73) Dreaming to get a new character through a new identity is a general interest, but actual personality is always revealed finally.

A person's appearance may identify her social status; thereby, Eliza needs to change her appearance, her clothing style, and the way she looks. In the play, some examples that prove a person's social class is revealed by their appearance and exemplified by a sentence in Act I, "It's all right: he's a gentleman: look at his boots. [Explaining to the note taker] She thought you were a copper's nark, sir." (Shaw, 13) Even e pair of boots reflects a person's social status. The writer takes attention to his characters' appearance while he is deceiving and makes us judge someone only by his appearance. The writer imposes how dirt or squalidity may affect a person's appearance. The internal contradicts also destroys someone's observes. However, the same question still goes on, although two men changed Eliza's appearance, will it be possible to create a new identity for her? In Act I, a quotation answers this question;

[Eliza] is not at all an attractive person. She is perhaps eighteen, perhaps twenty, hardly older. She wears a little sailor hat of black straw that has long been exposed to the dust and soot of London and has seldom if ever been brushed. Her hair needs washing rather badly: its mousy color can hardly be natural. She wears a shoddy black coat that reaches nearly to her knees and is shaped to her waist. She has a brown skirt with a coarse apron. Her boots are much the worse for wear. She is no doubt as clean as she can afford to be; but compared to the ladies she is very dirty. Her features are no worse than theirs; but their condition leaves something to be desired; and she needs the services of a dentist. (Shaw, 10)
George Bernard Shaw shows the reader that although Eliza tries to convince everyone that she belongs to a higher social class, she eventually becomes unhappy at the end because it is not her real identity. With his successful writing style, the writer focuses on themes such as transformation, gender roles, class roles, appearance and language to be mirrored in a more effective way. Language and communication skills play the same role as well as appearance. However, language is more important than appearance because words are more effective and similarly more deceiving. Even a single word can say a lot about a person. In Act I, the note taker emphasizes "the science of speech" (ibid., 19) and the way speech is portrayed as a significant factor. Language skills are associated with spirituality, as well. The way someone talks reflects her human spirit, and when someone speaks, they speak their soul, and everything inside their mind or heart. Honestly, Eliza speaks like the days she was florist because that was what she had in her heart. Eliza starts to talk old-style whenever she gets emotional. For instance, in Act III, Higgins mentioned;

As if I ever stop thinking about the girl and her confounded vowels and consonants. I'm worn out, thinking about her, and watching her lips and her teeth and her tongue, not to mention her soul, which is the quaintest of the lot. (ibid., 79)

Nobility is something blood-bound, or even if it is not, it takes too much practice that it will not happen in a few years. It is not necessarily a good thing too. According to Mr Doolittle, who inherited lots of money and was forced to improve her social class, she was angry and sad, criticizing that new money brings new problems that he could simply not handle. She was a stinking, poor flower lady without any good distinctive charm; so that Higgins and his friend turn her into a lady. According to Higgins, a good speech, good manners and a high-quality outfit is enough for a person to upgrade their positing in the pyramid of social class. The belief of one can change their social class by learning an utter lie. As seen, Eliza was acting different and weirdly; "The myth has a happy ending - the king and the ivory girl get married. But Eliza is not an ivory girl, she has her own thoughts and dignity. Eliza is much different from the shy ivory girl that the king loves, but an independent soul who seeks for equal love and independent life." (Haiyan\& Rongqian, 46)

Megalomania is an obsession with the exercise of power, and from what one can gather from Pygmalion, Professor Higgins is a megalomaniac. Not only he wants to upgrade the woman's social status, he liked the feeling of control and power over her. He wanted to play God on her, just like his mother did on him. As Higgins order Eliza to sit down or do something, we can see that his mother does the 
same with him. Higgins, not taking any criticism, values his mother's approval the most. This is not a typical answer or a question to be a matter of conversation between a mother and a son in a dialogue. Higgins' character has a little bit of 'Oedipus Complex,' with megalomania and 'God Complex.' God Complex is Narcissistic Personality Disorder (NPD) and characterized by the Diagnostic and Statistical Manual of Mental Disorders. Mrs Higgins asks, "Do you know what you would do if you really loved me, Henry?" and Higgins answers, "Oh bother! What? Marry, I suppose? (Shaw, 64) Shaw tailored an ancient story with late Victorian values and modern ideologies. Pygmalion effect shaped today's generation and extends the expectations of people from others, causing people to look for false perfections, by confronting more problems. Not only there is Pygmalion Effect in love relationships, but there is in business, education, family, and so many levels. The effect was first verified in studies that examined the relationship between teachers and students. If a teacher believes that a student is smart, the teacher should encourage the student to be a superstar (Rosenthal). It is all just a paradox and nothing, but a dilemma. The more we expect, the more we get disappointed. Expectations shall be kept at lowest, in order to be happy and not to have any internal crisis within one's self; "According to Foucault in all forms of power relations, the two agents are in an unequal stand of intercourse. For example, in the case of surveillance, the observed has no power to observe the observer; hence, the knowledge is produced by the observer about the observed." (Pirnajmuddin\& Arani, 150) "Shaw's Pygmalion has more deepness than the ancient one because in mythology, 'Pygmalion love' is pure and makes women much more submissive and inferior. However, in twentieth-century Pygmalion, women have standing, and they are not the property of their husbands or other men." (Gürses, 26) Pygmalion Effects' results are clearly revealed in the sentences below;

Apart from the things anyone can pick up (the dressing and the proper way of speaking, and so on), the difference between a lady and a flower girl is not how she behaves but how she's treated. I shall always be a flower girl to Professor Higgins because he always treats me as a flower girl and always will; but I know I can be a lady to you because you always treat me as a lady and always will. (Shaw, 112)

\section{CONCLUSION}

Pygmalion is an excellent example of a play that shows us, although it is hard to pressure on ourselves, we never escape our real personality to shape our self-identity through the help or touch of someone else. The magic will break down somewhere because the one that we believe is different. Young girl has a Cockney dialect, and a Notetaker is providing the continuity of the story, who is like the God in this drama, which makes this masterpiece so hard to indulge. The title of the drama, "Pygmalion," creates a specific dilemma; because of the fact that the story of mythical Pygmalion and Shaw's Pygmalion are similar to the meaning level. Bernard Shaw takes the attention of the reader to the social class differences between the poor and the upper class and highlights it by the transformation of a flower girl into a duchess. No matter what she does, according to Doolittle, Eliza will always be florist; because even though your social class is upgraded, everyone sees you as a character you were born.

\section{REFERENCES}

[1] Frazer, J. G. (1994). The Golden Bough, NY: Oxford University Press.

[2] Haiyan, Li, and Weng Rongqian (2016). "Eliza's Awakening in Pygmalion." Higher Education of Social Science, vol. 11, no. 3, pp. 42-48. URL: http://www.cscanada.net/index.php/hess/article/view/8970, DOI: http://dx.doi.org/10.3968/8970.

[3] Hamidi, B. A. (13 Jan. 2018). "Intertextuality in Iranian Literature: A Sculpture's Story." Golha-Ye-Hasrat, bagerihamidi.blogfa.com/post/5.

[4] Hamraz, Reza. (21 Nov. 2013). Bibliography of the Works of Dr Gholām-Hossein Sä'edi, ishiq.net/yaddast/6899.html.

[5] Gürses, G. (2018). "Social Reading through Pygmalion", The Book of Tragedies: A Collection of Short Essays on Literary Masterpieces, Ankara: Gece Kitaplığı.

[6] Hawthorne, N. (1983). The Birthmark. IA: Perfection Learning.

[7] Hedayat, S. (1998). Sayeh-Roshan [Penumbra], Tehran: Roozgar.

[8] Kennell, R., V. (2005). "Pygmalion as Narrative Bridge Between the Centuries". The Annual of Bernard Shaw Studies, v. 25, 73-81.

[9] Naderpour, N. (1957). Bot Taraash. http://www.naderpour.com/Poems-in-Persian/BotTarash.htm.

[10] Ovid. The Metamorphoses. (2009). Tr. Horace Gregory, NY: The Viking Press.

[11] Pirnajmuddin, H., and F. Arani (2011). "Discourse and Power in George Bernard Shaw's Pygmalion." Studies in Literature and Language, vol. 3, no. 3, pp. 146-152.

[12] Rosenthal, R., and L. Jacobson. (1968). Pygmalion in the Classroom: Teacher Expectation and Pupils' Intellectual Development. New York: Holt, Rinehart and Winston.

[13] Rumi (16 Oct. 2015). Dīvān-e Šhams-e Tabrīzī, Sonnet 1462. ganjoor.net/moulavi/shams/ghazalsh/sh1462/.

[14] Sa'edi, G. (1956). Pygmalion, Tehran.

[15] Shaw, B George (2005). Pygmalion. San Diego: ICON Group International. 